\title{
Artificial skin equivalent based on copolymeric hydrogel membranes with immobilized human mesenchymal stem cells
}

\author{
O.O. Kosenko, L.L. Lukash', Yu.M. Samchenko, T.A. Ruban', S.I. Lukash' ${ }^{1}$, Z.R. Ulberg, \\ N.P. Galagan ${ }^{2}$
}

F. D. Ovcharenko Institute of Biocolloidal Chemistry, NAS of Ukraine 42 Vernadsky Blvd, Kyiv, 03132, Ukraine

${ }^{1}$ The Institute of Molecular Biology and Genetics, NAS of Ukraine 150, Academician Zabolotny Str., Kyiv, 03143, Ukraine

${ }^{2}$ Institute of Surface Chemistry NAS of Ukraine 17, Ceneral Naumov Str, Kyiv, 03164, Ukraine

zulberg@bioco.kiev.ua

\begin{abstract}
The basic parameters of hydrogel membranes, which are important for their characteristics as potential biocompatible non-degradable wound coverings, have been optimized. Moderately hydrophobic and at the same time moderately hydrophilic membranes obtained on the basis of copolymerization of acrylamide and acrylonitrile were demonstrated to be biocompatible with mesenchymal stem cells. Small concentrations of highly dispersed silica introduced into a composition of hydrogel membranes were demonstrated to influence the cell cultivation positively. The technological conditions necessary for more effective and prolonged cultivation of cells on the surface of hydrogel membranes with improved exploitation parameters have been established.
\end{abstract}

Keywords: skin equivalent, hydrogel, mesenchymal stem cells, immobilization, cultivation, nutrient medium.

Introduction. Hydrogel membrane wound coverings are know to possess the following advantages: transparency, tight contact with the wound, high sorption capacity to wound exudation, aeration and migration of metabolic products, atraumatic use and safe removal from surface of the body [1]. Nowadays, hydrogel membranes for cultivation of autologous and allogenic cells are being developed.

Most commonly, differentiated skin cells, fibroblasts, and keratinocytes are used for medical

(C) O.O. KOSENKO, L.L. LUKASH, YU.M. SAMCHENKO, T.A. RUBAN, S.I. LUKASH, Z.R. ULBERG, N.P. GALAGAN, 2006 purposes [1-4]. However, sometimes hydrogel membranes are considered to be of little effect due to low mechanical rigidity, inclination to extinction, and low sorption capacity.

The use of mesenchymal stem cells (MSC) as a cell component of hydrogel membranes in development of artificial skin equivalents is viewed as perspective direction due to the fact that in certain microenvironment, these cells are capable of differentiating into different types of cells, including such as epithelial, tissue connective, muscular cells etc [5]. 
Earlier, using the method of radical copolymerization, we synthesized a series of hydrogel membranes on the basis of acrylamide, acrylonitrile, acrylic acid, which are applicable for MSC cultivation [6]. Performed comparative analysis allowed determining that non-ionogenic copolymeric hydrogels based on acrylamide and acrylonitrile acquired the optimal parameters for immobilization of human MSC. It was shown that the use of hydrogels with significant acrylic acid content is restricted due to considerable decrease in $\mathrm{pH}$ of nutrition medium, which is incompatible with vital activity of the cells.

The obtained data confirmed that the developed hydrogel involving MSC and/or differentiated skin cells is potentially applicable as effective temporal skin equivalent in treatment of burns (especially, massive burns with affection area of more than $70 \%$ and deep burns, involving hypodermic tissues), as well other damages of cutaneous covering. Therefore, we proceeded with the experiments on optimization of hydrogel parameters, important for their characterizing as biocompatible non-degenerative wound coverings. This paper presents the data on attempts to determine the technological conditions, necessary for more effective and long-lasting cultivation of cells on the surface of hydrogel membranes.

Materials and Methods. Synthesis of copolymeric gels. Copolymeric gels on the basis of acrylic monomers were synthesised by the method of radical copolymerisation of acrylamide and acrylonitrile in water environment at room temperature. $\mathrm{N}, \mathrm{N}$-methylene-bis-acrylamide was used as binding agent; gel-formation was initiated by oxidation-reduction system of potassium persulfate-sodium metabisulfite. Concentration of binding agent was wide-range modified during the synthesis of hydrogels. The samples with $0.188,0.375$, 0.654 , and $0.750 \%$ of N,N'-methylene-bis-acrylamide were investigated.

A series of hydrogel membranes with highly dispersed silica "Sylics" ("Biopharma" Ltd., Ukraine) were synthesised as well. For this purpose the hydrogel, containing $37.5 \%$ of acrylonitrile and $62.5 \%$ of acrylamide at binding agent concentration of $0.654 \%$, was added $0.25,0.5,0.75,1.0$, and $1.25 \%$ of FSP.
Mechanical properties of hydrogel membranes. Mechanical properties of evenly swollen copolymeric hydrogel membranes were determined using the modified Veiler-Rebinder apparatus. Sample hydrogel membranes of plate shape, thickness $(\mathrm{mm})-0.3$, width - 10, length - 20, were used for obtaining measurements. High accuracy geometric parameters were determined in each particular case using a ruler and micrometer. To obtain mean mechanical values of the procedure, 10 samples of each gel membrane were tested. Evenly swollen sample hydrogel membranes were fastened to the dynamometer spring using special soft fasteners. The possibility of evaporation and geometric parameters change was excluded due the sample being in cuvette with water throughout the experiment. Tension ratio of the sample was $1.53 \mathrm{C} 10^{-3} \mathrm{~m} / \mathrm{sec}$. Tensile strength and relative extension for hydrogels under investigation were calculated according to the formulae given below

$\sigma_{p}=F / S=F /(a \cdot b)$,

where:

F - load, $\mathrm{S}$ - sample section square, a, b - width and thickness of the sample.

Relative extension of hydrogel samples was calculated according to the following formula:

$$
\gamma=\frac{\lambda-\lambda_{0}}{\lambda_{0}} \cdot 100
$$

where:

$\lambda_{0}$ - initial length of the sample; $\lambda$ - sample length at the moment of break.

Optical properties of hydrogel membranes. Light refractive index of different composition copolymer hydrogel membranes was investigated using IRF-454 BM refractometer. Hydrogel samples $1 \mathrm{~mm}$ thick were placed between refractometer prisms. All measurements were made at room temperature. Mean value was calculated on the basis of three successive measurements.

Wetting of hydrogel membranes. The values of contact angles of wetting of hydrogel membranes were obtained by projection of the drop on the surface to the display and calculating the angle according to the correlation between the height of the circle segment and the chord length (method of B. D. Summ and Yu. V. Goryunov, unpublished data). 
Sorption properties of hydrogel membranes. To study the swelling of the samples they were emerged into distilled water and cultural medium DMEM solution with $5 \%$ solution of new born calf serum. After set time intervals, the samples were taken out, moisture surplus was removed from the surface using filtering paper, and then weighed using VLA-200-M scales. The amount of moisture absorbed by gel $(\mathrm{g} / \mathrm{g})$ was calculated using the following formula:

$\mathrm{Q}=\left(\mathrm{m}_{\mathrm{s}}-\mathrm{m}_{\mathrm{d}}\right) / \mathrm{m}_{\mathrm{d}}$

where $m_{s}$ and $m_{d}-$ mass of evenly swollen and dry sample.

Water content in hydrogels can be calculated as W $=\left(\mathrm{m}_{\mathrm{s}}-\mathrm{m}_{\mathrm{d}}\right) / \mathrm{m}_{\mathrm{d}} \cdot \mathrm{C} 100 \%$, then the cross-linked polymer content in hydrogel will be calculated as $\chi=100-\mathrm{W}$.

Biocompatibility of hydrogel membranes. MSC of 4BL2 line were cultivated in standard DMEM medium ("Sigma", USA) adding 5\% solution of new born calf serum ("Sigma") and antibiotics - penicillin and streptomycin, 100 units per $\mathrm{ml}$, at $37^{\circ} \mathrm{C}$ at the thermostating conditions. For typical passaging the cells were cultivated with monolayer formation on the surface of glass bottle or Petri dishes ("Anumbra", Czech Republic, $\mathrm{d}=35 \mathrm{~mm}$ ). To test hydrogel membranes for biocompatibility, sterile dried membrane samples were placed into Petri dishes, pored over with standard cultural medium for at least 5-6 hours for swelling. Then, after removing surplus cultural medium, cell suspension $\left(10^{5}\right.$ of cells in $2 \mathrm{ml}$ of cultural medium) was applied onto adapted membranes. The method of biocompatibility testing for different types of hydrogels has been earlier described in [6]. The cell cultures were observed under inverted microscope and the immobilizing capability of MSC on the hydrogel membranes, adhesive characteristics, possibility of growing and multiplying, and their morphology were investigated. Glass Petri dish surface was selected to be the control.

Results and Discussion. A significant number of copolymeric hydrogels (from homopolyacrylamide hydrogels to hydrogels with equivalent correlation of acrylamide-acrylonitrile links) have been synthesised. Further increase in acrylonitrile concentration turned out to be impossible due to limited dissolubility in water.

The research showed that variation in monomer correlation influences significantly physical-chemical

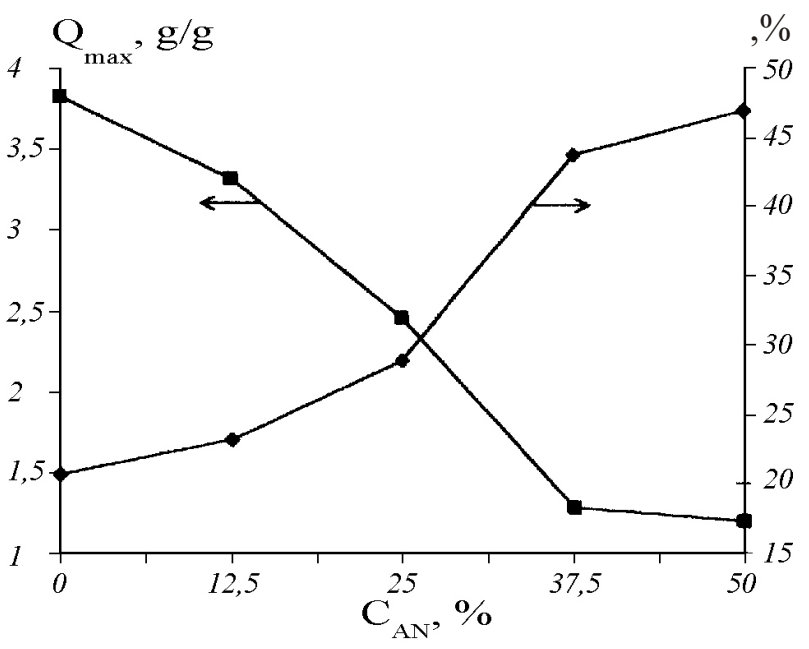

Fig.1 Dependence of equilibrium degree of swelling of hydrogels and content of cross-linked polymer in them on acrylonitrile links concentration.

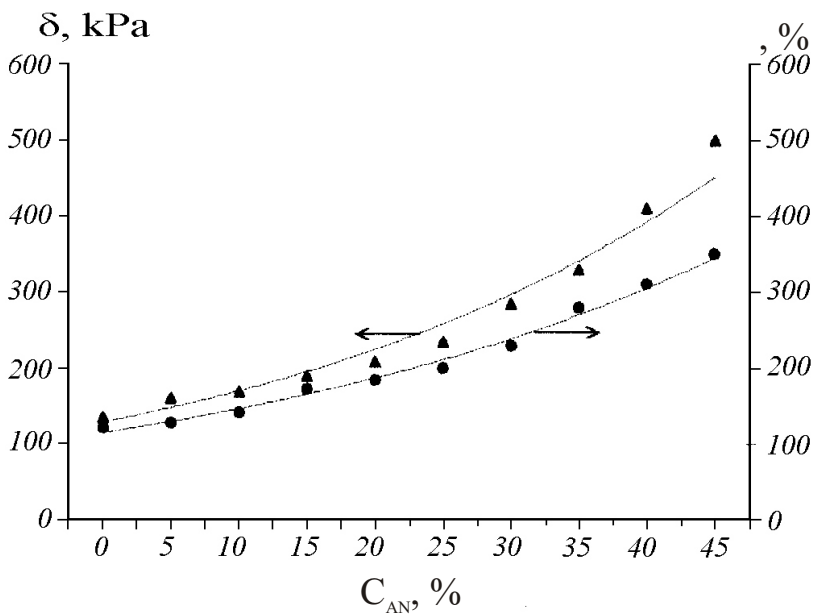

Fig.2 Dependence of tensile strength and relative extension of hydrogels on acrylonitrile links concentration.

properties of hydrogels. Thus, Fig.1 (curve 1) shows that in accordance with substitution of hydrophilic acrylamide links for hydrophobic acrylonitrile ones, equilibrium water content, which these links may hold, decreases. Similarly, concentration of binding agent influences the level of equilibrium water content in hydrogels. Whereas, solid phase content, responsible for physical-mechanic properties, increases (Fig.1, curve 2). At the same time, tensile strength and elasticity are correlated with the increase of cross-linked polymer content in hydrogel, and, therefore, with the increase in the share of polymer links, which bare mechanical loading (Fig.2). 


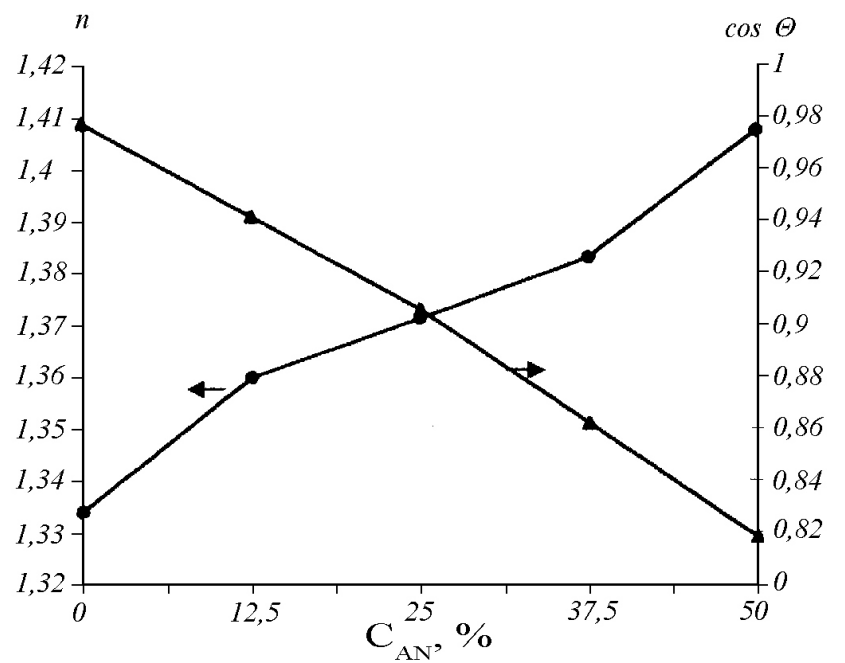

Fig.3 Dependence of index of refraction and contact angles of wetting of hydrogels on acrylonitrile links concentration

Two more parameters are influenced by the increase in hydrophobicity of hydrogels - index of refraction increases and $\cos \Theta$ (end contact angles of wetting) decreases (Fig.3). These parameters may be used for express-evaluation of hydrophilic-hydrophobic balance of copolymeric hydrogels, as the investigation performed showed that moderately hydrophilic and at the same time moderately hydrophobic gels acquire a complex of properties necessary for cultivation of mesenchymal cells.

Hence, Fig.4, analysis of microphotos of cell populations on the surface of hydrogel samples depending on their chemical content, showed that monomers of the whole investigated range of concentrations are specific for binding, spreading, and multiplication of MSC. However, the formation of monolayer was observed on the surface of moderately hydrophilic and moderately hydrophobic sample only, containing $37.5 \%$ of acrylonitrile at the binding level of $0.654 \%$.

At the same time, hydrogels with indicated copolymeric content are specific for optimal physical-chemical characteristics (Fig.2), as hydrogels with higher acrylonitrile content are firmer, yet not transparent, which is essential for controlling the wound healing process. Therefore, further investigation on optimisation of hydrogel membranes content for immobilisation and cultivation of MSC will involve the sample containing $37.5 \%$ of acrylonitrile.
The literature data [7] indicate that highly dispersed silica is involved in adsorbing interaction with the surface of cells, moreover, this interaction is conditioned, first of all, by electrostatic forces, occurring between negatively charged silica particles and quaternized ammonium groups of membrane phospholipids. Further contacts between cells and highly dispersed silica may be strengthened by means of hydrogen and Van der Waals interactions. At the same time highly dispersed silica may lead to denaturation of membrane proteins [8].

Considering these facts, it was logical to investigate silica influence on MSC cultivation.

The latter influence was shown to be of clear-cut concentration dependent character. The introduction of $0.25 \%$ FSP results in almost 5-fold increase in population of viable cells (comparing to control), further increase in concentrations $(0.5$ and $0.75 \%)$ resulted in insignificant increase in MSC population, and silica concentration, higher than $1 \%$, results in cells death.

Therefore, it is possible to conclude that at the condition of minimal silica content in hydrogels, adsorption interactions will prevail, promoting interaction of cells with hydrogel surface and nutrition medium, whereas high silica concentrations will cause the destruction of cell membranes. Intermediate silica concentrations in hydrogel carriers are notable for their competitive influence of both mentioned processes.

Conclusions. Therefore, current work presents the optimized parameters of hydrogel membranes, which are important for their characterization as potential biocompatible non-degradable wound coverings.

Moderately hydrophobic and at the same time moderately hydrophilic membranes, obtained by copolymerisation of acrylamide and acrylonitrile monomers, were confirmed to be MSC biocompatible.

It was demonstrated that minimal concentrations of highly dispersed silica promote multiplication of mesenchymal stem cells.

Necessary technological conditions for effective and long-lasting cultivation of cells on the surface of hydrogel membranes with modified exploitation properties were determined. 


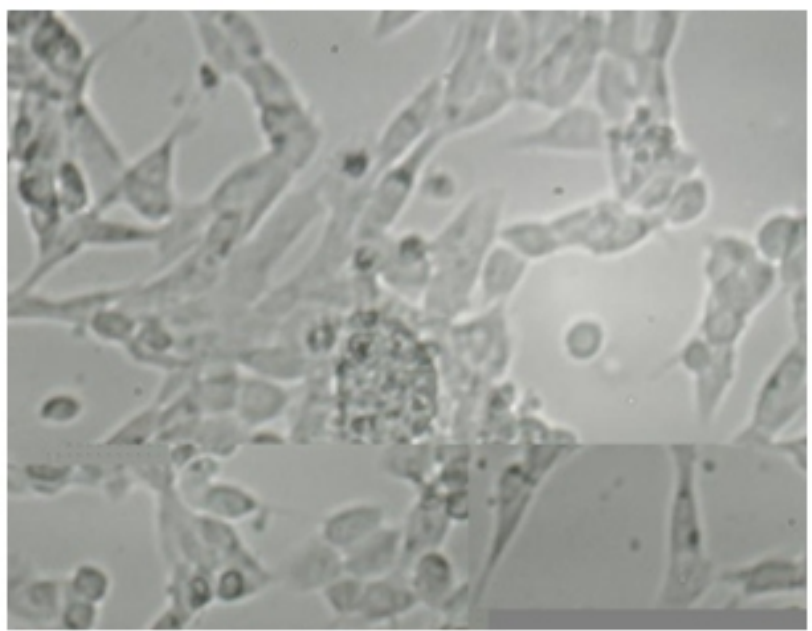

$a$

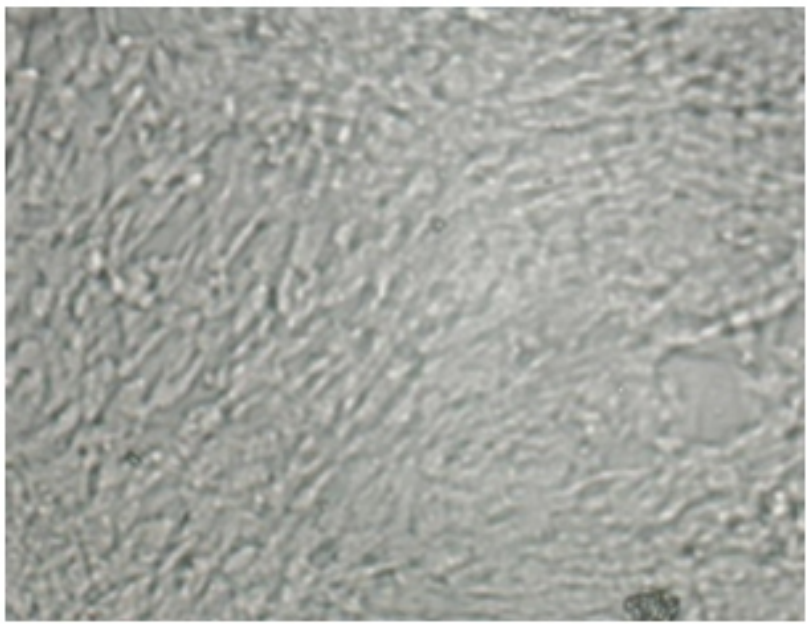

c



\&

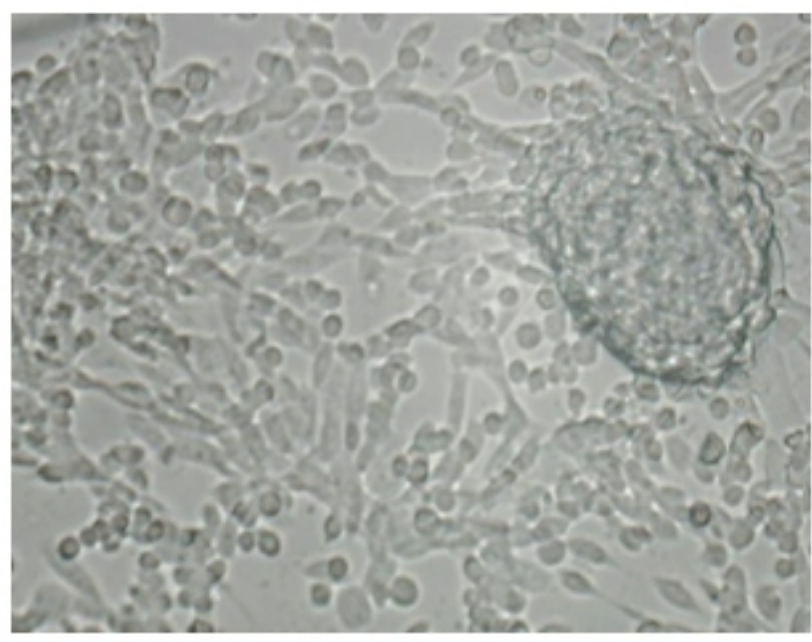

$b$

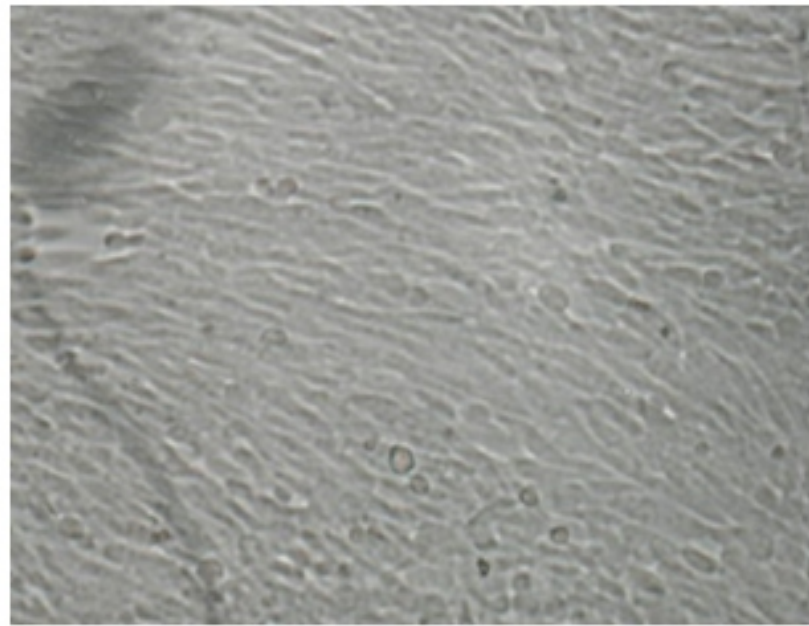

d

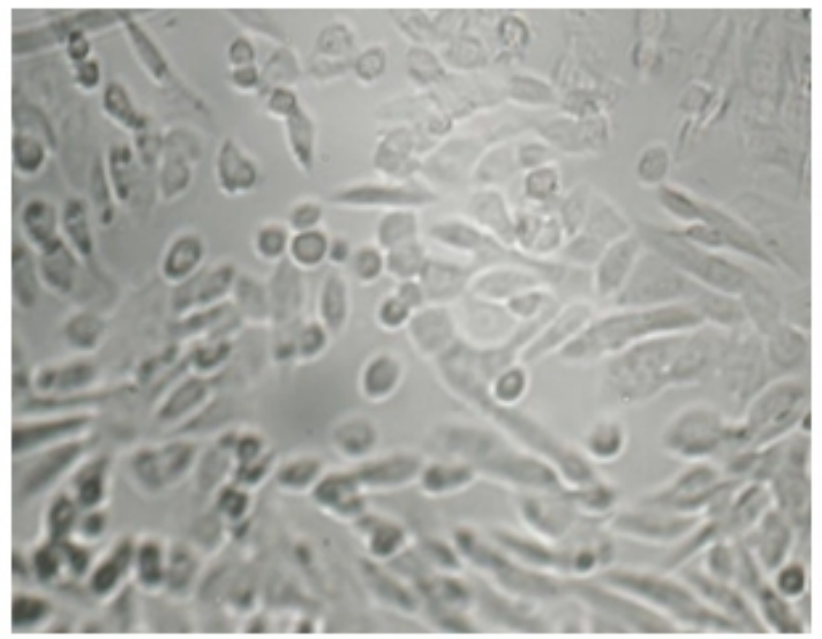

$f$

Fig. 4. Cell populations on the surface of hydrogel samples with different acrylonitrile concentration (\%):a-0; b-12,5; c-25; d-37.5; e-50; f-control (x100) 
О. О. Косенко, Л. Л. Лукаш, Ю. М. Самченко, Т. А. Рубан, С. И. Лукаш, 3. Р. Ульберг, Н. П. Галаган

Искусственный эквивалент кожи на основе сополимерных гидрогелевых мембран с иммобилизованными мезенхимальными стволовыми клетками человека

\section{Резюме}

Оптимизированы базовые параметры гидрогелевых мембран, которые важны для их характеристики в качестве потенциальных биосовместимых недеградируюших раневых покрытий. Показано, что умеренно гидрофобные и одновременно умеренно гидрофильные мембраны, полученные на основе сополимеризации акриламида $и$ акрилонитрила, являются биосовместимыми для мезенхимальных стволовых клеток. Показано, что небольшие концентрации высокодисперсного кремнезема, вводимого в состав гидрогелевых мембран, положительно влияют на размножение клеток. Установлень технологические условия, необходимые для более эффективного $и$ длительного культивирования клеток на поверхности гидрогелевых мембран с улучшенными эксплуатационными качествами.

Ключевые слова: эквивалент кожи, гидрогель, мезенхимные стволовые клетки, иммобилизация, культивирование, питательная среда.

\section{REFERENCES:}

1.Парамонов Б. А., Порембский Я. О., Яблонский В. Г. Ожоги.-Санкт-Петербург: СпецЛит, 2000.-488 с.2.Пат. RU $2152800 \mathrm{C} 1$, A 61 K 39/39, 48/00. Method of culturing and modification of heterogeneous mammalian cells / D. V. Zybin, A. G. Kotelevits // Publ. 2000-07-20.

3.Пат. UA 67880 C2, C 08 F 220/56, A 61 K 35/48, A 61 L 27/52. A transplant removing defects and restoring functions of biological tissues, and a method for the preparation thereof / I. O. Zavhorodnii, P. S. Moisieiev // Publ. 2004-07-15.

4.Пат. WO 81/01290, C 08 F 220/56, C 08 L 33/26. Polyacrylamide gel for medical and biological application and method of its preparation / V. Gashinsky, A. Sokolyuk // Publ. 1981-05-14.

5.Jiang $Y$. Pluripotency of mesenchymal stem cells derived from adult marrow // Nature.-2002.-418.-P. 41-49.

6.Косенко О. О., Лукаш Л. Л., Самченко Ю. М., Рубан Т. А., Ульберг 3. Р., Лукаш С. I. Кополімерні гідрогелеві мембрани для іммобілізації та культивування стовбурових клітин людини // Біополімери і клітина.-2006.-22, №2.-С. 143-148.

7.Depasse J., Warlus $J$. Relation between the toxicity of silica and its affinity for tetraalkylammonium groups // J. Colloid and Interface Sci.-1976.-56.-Р. 618-621.

8.Медицинская химия и клиническое применение диоксида кремния / Под ред. А. А. Чуйко.-Киев: Наук. думка.—2003.—414 с.

Надійшла до рдК 5411.182644 